\title{
Inxeba (The Wound), Queerness and Xhosa Culture
}

\author{
Lwando Scott \\ Centre For Humanities Research, University of the Western Cape, Bellville, South Africa
}

\begin{abstract}
This article focuses on the controversy caused by the release of the film Inxeba (The Wound). Inxeba depicts a complex intersection of rites of passage, masculinities, queerness and the relationships between men in a homosocial environment within a Xhosa cultural setting. I argue that the subject matter of same-sex intimacy in the film challenges dominant constructions of Xhosa masculinities by going to the foundation of dominant Xhosa masculinities, namely the male initiation process. The film poses a challenge to Xhosa culture by boldly asking: what is the position of Xhosa culture on same-sex intimacies? The film depicts samesex intimacy that takes place in one of the most sacred of Xhosa cultural spaces. In the article, the film is analysed as a conversation initiator, through which ideas about same-sex desire, Xhosa culture and ultimately African sexuality can be scrutinised and debated.
\end{abstract}

\section{KEYWORDS}

Xhosa culture; same-sex desire; queer; Inxeba; masculinity

\section{Introduction}

The release of the South African film Inxeba directed by Trengove (2017) in early 2018 was mired in controversy and contestation because of the same-sex intimacy subject matter of the film, and in particular, the Xhosa cultural setting within which same-sex intimacy was shown to take place. Inxeba is a film about the lives of Xhosa boys and men who are involved in ulwaluko, a traditional Xhosa rite of passage that includes circumcision for Xhosa boys ${ }^{1}$ in a process meant to make boys into men. The film depicts an emotional and sexual encounter between some of the men during the weeks of the initiation process. Inxeba depicts the complex intersections within Xhosa culture, of rites of passage, masculinities, queerness and the relationships between men in a homosocial environment. When the film premiered nationally there was a proposed boycott of it by the traditional leaders, the Xhosa Chiefs from the Eastern Cape, through the Congress of Traditional Leaders of South Africa (Contralesa) (Collison 2018; Masuabi 2018). Threats were issued to theatres showing the film in parts of the Eastern Cape (Zeeman 2018). Death threats were issued to the actors in the film, particularly to the lead actor Nakhane Touré, who was most vocal about the importance of the film and the message behind it (O'Reilly and Madibogo 2018). Ironically, the violence, or the threat of violence, following the release of the film echoed the violence partly critiqued by the film. Furthermore, after a formal complaint was lodged against the film, the Film and Broadcasting 
Complaints Commission changed the age restriction rating of the film from 16 years for sex and strong language to $18 \mathrm{X}$, which is a designation for hardcore pornography (Khoza 2018). The pornography rating reveals the prejudice and negative attitudes towards same-sex intimacies. The change in rating also meant that the film couldn't be shown in regular film theatres. A court ruling eventually ordered the film rating to be changed back to 16 .

When the film was released there were many debates on social media and news outlets about the film and its legitimacy (Siswana and Kiguwa 2018). In all of the debates, disagreements and outright rejections of the film, it was clear that the film touched a nerve and started conversation. There were people who supported the film, but the voices that were distinctly audible were those who spoke up against the film.

Although controversial and divisive, as many people had strong opinions about the film, the film had created an opportunity for conversation amongst South Africans (Siswana and Kiguwa 2018). My argument in this article is that the film challenges dominant ideas of black masculinity. The film specifically challenges dominant forms of Xhosa masculinities and does so by going to the foundation, the "factory" of dominant Xhosa masculinities - ulwaluko. I am interested in the film because of the possibilities created by the film: both through its existence as a work of art that speaks to the realities of some Xhosa queer men, and also because of space it created for a conversation about the intersection of queerness, Xhosa masculinities and Xhosa culture. The film poses a challenge to Xhosa culture itself, by boldly asking what the position of Xhosa culture is on same-sex intimacies, because not only do these intimacies exist, they exist deep in the most sacred of Xhosa cultural spaces.

During the public contestations, I was struck by the strong homophobic reactions against the film from Xhosa men particularly, as these reactions were ironically part of the subject matter of the film. In part, the film addressed the difficulties of queer Xhosa boys and men who are navigating tradition and cultural practices, and it showed how powerfully their experiences are shaped by heteronormative and homophobic culture. In this article, I highlight the irony of Xhosa men strongly rejecting a queer film while through their rejection exhibiting the very dominant masculinity tropes that are critiqued by the film. Discussed here is the content of the film and the way it intersects with and speaks to the strong reactions from particularly Xhosa men who reject the film. In this article, I demonstrate that these strong reactions are linked to the direct critique of the dominant forms of masculinity in the film, and that Xhosa culture needs to account for the lives of queer boys, men and masculinities in the culture. Furthermore, the film and the debates surrounding it necessitate a critique of the homogenous narrative about what precisely Xhosa culture is and includes because those who strongly rejected the film saw themselves as arbiters of Xhosa culture. There are possibilities created by the film, chief amongst which is to encourage viewers to think more critically about the making of Xhosa men. To think critically about the possibilities created by the film is to ask what is at stake here with regards to blackness, queerness, gender normativities, culture and the intersection of all of these concepts. Considering the postcolonial and post-apartheid context of South Africa, I wonder about the possibilities of Inxeba as it explores the intersections of culture, traditions, "modern" identities and the homosocial relationships between men. 
When I attended a pre-release screening of the film at a film festival in Cape Town and before the film received wider release, I knew that the film would be controversial and spark conversation. What I did not anticipate was the level of animosity and the threats of violence that would be levelled at the film and those involved in it. I watched the film with a group of friends, all of us Xhosa and queer, and we all agreed that some would not like the display of Xhosa culture, particularly because African cultures and queerness are discursively articulated as mutually exclusive. As I demonstrate in "Harnessing the power of queerness", growing up queer but also part of Xhosa culture was complicated because from an early age I knew the limited ways manhood was understood within the culture and I knew my queerness was a failure of what was expected (Scott 2019). The mutual exclusiveness of queerness and Africanness is probably most readily exemplified in the ubiquitous yet tired aphorism "homosexuality is unAfrican". The falsehood of this narrative has been the subject of much scholarship. For example in the work by Dunbar Moodie (1988), Murray and Roscoe (1998), Kendall (2001), Epprecht (2004) and Morgan and Wieringa (2005) it is shown that there is a rich history of same-sex intimacies on the African continent. The question then is what happens when we centre African queerness; in other words, what are the possibilities entailed in the desire that Xhosa men have for each other? What can we possibly learn from the conversations created by the film about masculinities? What can we do with what we have been given, both by the film and by the reactions to it? What kind of conversation does this film enable around the multiplicity of Xhosa masculinities? The arguments made here are indebted to Ratele's $(2014,2017)$ influential arguments on African psychologies of boys, men and masculinities in post-apartheid South Africa.

\section{Inxeba and Black Queer Bodies}

Queer people have always been a challenge to dominant constructions of masculinity (Heasley 2005). Ratele attributes this challenge to the simultaneous belonging and unbelonging of queer African people arguing that "perhaps the most disquieting challenge that non-conforming, queer Africans pose for masculine traditionalism is that they represent the fact that 'we' can be 'us' and 'them' at once" $(2013,152)$. The existence of queerness or queer people in the film Inxeba, and the reactions towards the existence of queerness in the film, make obvious this challenge to traditional understandings of masculinities. Inxeba forces Xhosa communities to engage with queerness and with what queerness means for Xhosa masculinities. Inxeba encourages deeper thought about black men's bodies. It encourages a thoughtful reflection on queer bodies, and how they intersect and interact with idealised Xhosa masculinities. It also gently invites us to ponder the making of Xhosa masculinities. Inxeba challenges Xhosa culture and the men who see themselves as vanguards of Xhosa cultural practices, and in the process creates a space for possibilities, particularly for conversations about culture, queerness and masculinities.

In order to be thorough in my reflection, I would need to be vigilant of the social and historical context in which the film takes place. The film and the reactions towards the film, are also to be understood in context - that of a rapidly changing democratic South Africa where South Africans are free to construct themselves, including their sexual selves. The sexual orientation protection clause in the South African constitution has enabled queer 
South Africans to be visible and to make claims to rights as citizens in the country. Indeed, Pierre De Vos has argued that the sexual orientation clause "contributed to the constitution of lesbian and gay identity" in post-apartheid South Africa $(2001,196)$. It is this constitutionally mandated freedom that has led to the legalisation of same-sex marriage in South Africa (Judge, Manion, and de Waal 2008). Although marriage equality has been achieved, a majority of queer South Africans still face homophobic violence and other violent exclusions (Mkhize et al. 2010; Judge 2018). Through colonialism, and then apartheid, the social context of South Africa is one where black bodies have historically been subjected to subjugation. In the context of colonial history, the black body has always been seen through what Mbembe $(2001,1)$ called "negative interpretation", an interpretation that has failed to humanise black love and black expressions of affection and intimacy. The irony, of course, is that the film Inxeba, and the reactions against the film, are responding to the "negative interpretation" of the representation of the black body. While the film sees black queer bodies in a positive light, and inserts queer bodies in Xhosa culture, those who see same-sex attraction as "unAfrican" regard the existence of same-sex desire in Xhosa culture as damaging to Xhosa culture.

In the history of colonial oppression, where the seeds of the "homosexuality is unAfrican" mantra were sown through laws such as the penal codes, Inxeba offers us alternative ways of thinking about the queer black body, and how it can be represented. It disrupts the heteronormative representations of black bodies in post-apartheid South Africa and asserts that there are other bodies in this landscape. The film also affirms alternative ways of sexualising the African body that are not hinged on the dominant heteronormative Western standard. Indeed, Amadiume (1987) and Oyěwùmí (1997) have made significant contributions to our understanding of the complex history of sex and gender systems in African societies, and their critiques of the imposition of Western Christian norms on African sex and gender systems offer us alternative ways of seeing African bodies. Inxeba articulates different ways of scripting Xhosa male bodies, scripting that moves away from the dominant masculine and heteronormative tropes inherited through the colonial project. The alternative representation of black bodies is particularly salient for black men's bodies because in the South African context black men's bodies have historically been linked to slave-like labour in the mines (Delius 2017), and black men were seen only as garden boys for white settler gardens (Ally 2009; Jansen 2019), subject to the brutalisation by the state apparatus enforcing apartheid policies (Sachs 1970; Pigou 2001). In Inxeba black men's bodies invert this script: black men's bodies relate to each other in ways that are not normally seen, and in ways that force the viewer to challenge their ideas of what exactly black bodies are supposed to be like and to do.

\section{African Traditions, African Masculinities}

Over the past 20 years, there has been a proliferation of studies focusing on African masculinities as demonstrated by the Changing Men in Southern Africa volume edited by Morrell (2001), the African Masculinities volume edited by Ouzgane and Morrell (2005) and the Masculinities in Contemporary Africa volume by Uchendu (2008a). These volumes focus on different parts of the African continent and demonstrate the complexities and vast range of African masculinities. This article is in conversation with these articulations of African masculinities, and also contributes to this growing body of work. In the 
South African context, Ratele $(2013,2014,2017)$ has paved the theoretical path for us to think about African masculinities in their contexts. Ratele argues for psychology of African boys, men and masculinities that is situated, stating that "the psychology of boys and men still has to fully turn to African boys and men as African boys and men, rather merely as boys and men in Africa" $(2017,16)$. This is important considering the history of colonialism and apartheid in South Africa, and how the legacies of these systems continue to shape African masculinities. Ratele, from within his discipline, pushes for an African-centred psychology, but his insights are useful to other areas of study and raise questions about African cultures, African traditions, and how these are negotiated in the contemporary moment with regard to gender and sexuality.

In trying to make sense of contemporary African masculinities, Uchendu (2008b) interrogates historical narratives of African masculinity and asks provocative questions about African manhood. Uchendu's (2008b) work highlights the negative constructions of African boys, men and masculinities by Eurocentrism and how those negative constructions negate the complexities of African traditions and masculinities. To counter Eurocentrism, Ratele pushes for a critical studying of men in Africa that appreciates "a man as part of the group called men is to study them as ethnic or national subjects" $(2008,18)$. In this way, Ratele is arguing that African masculinities are different from masculinities from other parts of the world, particularly white masculinities. This has implications for how we think about men and try to understand why men do what men do in a particular context. This is by no means a way of excusing toxic masculinity behaviours, but it is a way to ground and understand culturally specific behaviours in men situated in the African continent. In this way, we are better able to deal with or combat gender inequality because our interventions will be informed by a critical understanding of African men in context.

The language used in debates about African cultural practices is often itself contentious. Words like "culture" and "tradition" often have different meanings for different people, therefore it is necessary to be specific when using these terms. The argument made by Ratele (2013) is a case in point, that the very language of "traditional masculinity" makes assumptions about the homogeneity of traditional masculinities. Ratele (2013) problematises the use of "traditional masculinities", a term that automatically creates authentic and less authentic masculinities. Ratele argues that "it is productive to think of all forms of and claims around sexuality and gender, in particular forms such as gay masculinity, lesbian masculinity and other non-normative sexualities, as never outside of tradition" $(2013,135)$. Here, before we can trouble what tradition creates, the very notion of tradition is troubled. This is a powerful intervention that at its core understands masculinities as existing in a continuum and not in a hierarchy, and he argues for a place for gender non-conforming masculinities.

This means that in the studies of African masculinities, gender non-conforming and queer masculinities must be taken seriously. In other words, the proposal made by Sakhumzi Mfecane for African centred theories of masculinities, "theorising masculinity based on popular African concepts of personhood" $(2018,291)$ must include gender non-conforming and queer masculinities. Ulwaluko is a complicated ritual that involves multi-layered social arrangements (Gqola 2007), and the popular discussions around ulwaluko often lack depth and seriousness. What becomes clear, is that the power of the queer within Africa is to disrupt the taken for granted normativities in African cultural practices. 
Indeed, Ratele argues that "queer Africans disturb the 'traditionalist' sexual and gender order because they are both part of normative, traditionally acceptable families, part of 'traditional communities', as well as having part of their lives disavowed" $(2013,152)$. The falsification of the unbelonging or the unAfricanness of queer Africans serves to justify their discrimination and excommunication because they pose a challenge to hegemonic ideas of traditional cultural practices. This challenge to power has implications for gender relations, particularly the undermining of gender inequality by blurring the gender binary lines.

The rite of passage of ulwaluko is about tradition, which means it is about having a history; it is about culture, which means it is about belonging; it is about boys turning into men, which means it is about personhood. The conversation between feminist scholar Pumla Gqola and artist and art historian Thembinkosi Goniwe (2005) illuminates the high stakes involved in the debates about the rite of passage of ulwaluko. Goniwe argues that "ulwaluko functions in the construction of sexuality and masculinity both positively and negatively, despite the confusion fuelled by the media due to the current crisis the ritual confronts" $(2005,81)$. Goniwe is speaking here about the value this rite of passage has for Xhosa men, but also the destructive elements, for example, the kind of man that is produced by the rite of passage. When Goniwe speaks of the "current crisis" he is referring to the death of some of the boys while going through the rite of passage that makes headline news every June and December in the South African media, the times when the initiation schools commonly are held. Goniwe argues that we need to "problematise fixed positions or male perspectives that are learned, transmitted and naturalised by ways of traditional and socio-cultural practices, which ulwaluko is, among others" $(2005,83)$. In other words, we cannot only look at the positive aspects of the ritual and negate the destructive elements.

In the conversation with Gqola, Goniwe states that his artistic work speaks to the complexities of black masculinities, and that he seeks alternative constructions of black sexualities but is mindful of the value of culture and does not want to lose culture. In many ways, this threatened loss of culture is at the centre of the debates about the film Inxeba because the legacy of colonialism is still with us and impacts how African cultural practices are seen. It is the multiplicity of culture and tradition, the colonial past and patriarchy, that make the debates about ulwaluko so contentious in the contemporary moment. Indeed, Gqola argues that

some of the protectiveness around ulwaluko hinges on this sense of threat of erasure. It seems to me that there are three things happening at once: conservative (Xhosa) masculinist gatekeeping; the justified anger at specific media idioms of (again) casting black masculinity as savage deviant, dangerous, barbaric and therefore easy to translate into shorthand; and lastly, the collective memory of erasure and colonialist/anthropological intrusion into so many other sites of self-making which leads to a protectionism around this particular site. $(2005,83)$

The protectionism around culture, borne of the negative interpretation of African life, creates an environment of what Ratele calls the "retribalization" $(2013,138)$ of African life in defence of African culture. It is understanding this complex history that enables us to understand the fallout over the film Inxeba, the contempt for gender non-conforming masculinities and for queer people. This by no means allows for a justification of the brutality that is visited upon those who question patriarchal and traditional power, and 
how it is simultaneously against imperialism but is invested in the defence of hegemonic masculinities. On the contrary, we are encouraged by these scholars to have a more critical and nuanced understanding of gender, particularly African masculinities, and the ways that power operates in African specific environments.

\section{Inxeba - The Film}

Inxeba is a film set in the bushes and hills of the rural Eastern Cape of South Africa. The Eastern Cape is where the majority of Xhosa speaking people live in South Africa. The film was directed by John Trengove, a white South African. His race was part of the contention in the fallout over the film since some black people questioned why a white director was directing a film about black culture. The question over Trengove's involvement almost always overshadowed the involvement of the black co-writers of the film, Thando Mgqolozana, Malusi Bengu and Batana Vundla. The film is centred on three main characters, who are all playing different roles in the process of ulwaluko. Kwanda (acted by Niza Jay Ncoyi) is a young initiate who lives in the city of Johannesburg, where his father moved when the family left the village in the Eastern Cape. Kwanda is in the Eastern Cape to take part in the rite of passage of ulwaluko in order to become a man. The other character is Xolani (played by Nakhane), also affectionately known as " $\mathrm{X}$ ", who is Kwanda's designated caregiver who oversees Kwanda as he heals from his circumcision. Xolani is also responsible for teaching Kwanda the ways of being a man since he has already been through the rite of passage process. The third central character is Vija (played by Bongile Mantsai), who is a friend to Xolani and is also a caregiver to young initiates. Xolani and Vija underwent the rite of passage of ulwaluko together years before and see each other every year during the initiation season when they return as caregivers. The film follows the interactions of these three men as they navigate tradition, rural versus city dichotomies and same-sex desires.

Right from the beginning of the film, we are introduced to the politics of gender that carries on through the film. When Kwanda's father, Khwalo (played by Gabriel Mini) is having a discussion with Xolani about his son Kwanda, who is about to undergo the initiation process, he instructs Xolani "I want you to be firm with my son ... the boy is too soft". As a viewer, this is an introduction to the gender politics that are not just about to play themselves out in the film, but also reflect dominant gender politics in Xhosa culture specifically, but also South African gender politics in general. Kwanda's father obviates his struggle with his effeminate son, who is attached to his mother, and is clearly not invested in the cultural rite of passage, and throughout the film the son expresses desire for his comfortable and "soft" life back in Johannesburg. Kwanda's softness is a source of anxiety in the film with Vija and Xolani calling Kwanza the "soft boy" when they are discussing him. In an environment that is characterised by dominant ideas of how masculinity must be practised, through his non-conforming masculinity Kwanda challenges the other men. Here Ratele's (2013) articulations for the appreciation of multiple masculinities existing on a continuum are salient. Kwanda's softness, his effeminate disposition is articulated as something that must be "fixed". Both Kwanda's father and Vija see the man-making process of ulwaluko as something that can "fix" Kwanda, which of course suggests that something about him is broken. The gender tensions surrounding Kwanda stand in for gender tensions within Xhosa culture in that Xhosa 
manhood is seen as an antithesis to femininity. In Xhosa culture, as in South African culture more widely, gender equality is still beyond reach because women continue to be seen as inferior to men. Kwanda's softness is threatening and needs to be corrected precisely because it is seen as threatening to the power of the gender order.

The relationship between Xolani and Vija is fraught because the pair only see one another during the initiation season on the mountain. The initiation of boys usually takes place during the summer, in December, when people have time off from school and work. In the beginning of the film, we see that Xolani works at what looks like a warehouse facility driving a forklift. It is the last day on the job, and after this day he proceeds to go to the mountain. As the film progresses, we learn that, unlike Xolani who is single, Vija is married to a woman and has three children. During their first one-on-one meeting, there is silence between them, all the communication is non-verbal, and as they walk in the woods, Vija follows Xolani, and they find a deserted house-like structure where they proceed to have sex. You only hear their grunts and moans, no conversation is heard between them. They only speak when the sex is over. As a viewer, I imagined that this scene has played itself over and over in the previous years they had been coming to the mountain. In another stolen moment between Xolani and Vija, when Xolani goes in for a kiss, Vija pushes him away. Using his hands Vija directs Xolani to give him oral sex instead. When the pair meets up again, Xolani gives Vija money, ostensibly to support his family seeing that Vija has three children and Xolani is alone. Vija and Xolani finally share a kiss, and it is presented on screen as a tender moment. They then embark on a revealing conversation, where Xolani admits to Vija that he is lonely. He says "I live alone.... I eat alone ... I come back for you". Not knowing how to process these emotions, Vija says that he can't give Xolani what he wants and proceeds to return the money to him. They get into a physical fight, and Xolani threatens never again to come to the mountain.

It must be stressed that in trying to understand Vija and Xolani, one must account for the heteronormative and homophobic environment they navigate. Not only does the environment on the mountain contain homophobic and dominant ideas of masculinity, they themselves comply with those ideas. Even as Xolani and Vija engage in sexual intimacies with each other on the mountain, and Xolani is on the verge of professing his love, they harbour homophobia within themselves. Here there is a doubleness, a contradictory ambiguousness, in that while there is a rejection of Kwanda's non-conformity and queerness, there is a secret embrace of same-sex sex. The way that Xolani and Vija are with Kwanda is also complicated. The disdain towards Kwanda is aptly captured when Vija says to Kwanda "you are here to fuck up our ways". Here Vija is addressing the queerness of Kwanda, which of course is ironic because Vija has been engaging in "fucking" up, literally, with Xolani on the mountain for what seems to be years. Here Vija can be read as deflecting from the ways that he himself is implicated in the "fucking" up of the culture. It is also Vija who says to Kwanda "they want to be like you", speaking about the other initiates wanting to be like Kwanda who is read as middle-class and from the big city. This demonstrates a complicated ambivalence, a simultaneous rejection of Kwanda and desire to be like Kwanda. The relationship that Vija and Xolani have with Kwanda is a multi-layered intersection of class, gender, sexuality and culture and how the three central figures in the film are caught up in systems bigger than their individual parts.

It is Xolani who demonstrates what can be read as empathy towards Kwanda, but the demonstration of empathy is not without complications. During their time on the 
mountain, initiates are often visited by elder men, and partake in homosocial bonding. During these bonding sessions, the art of being a Xhosa man is practised, and part of that art is the ability to introduce yourself as a man amongst other men. When this gathering was taking place in the film, Kwanda refused to introduce himself as a man in front of the elders, like the other initiates were doing. He was defiant and in many ways understandably so, because in the presence of the men there he was already being read as a "failed" man. Empathising, Xolani comes to Kwanda's defence. Xolani says that when Kwanda is ready, he will introduce himself and he shouldn't be forced to perform Xhosa manhood at this time. The relationship between Xolani and Kwanda comprises of a difficult power dynamic in that Kwanda is the initiate and is dependent on Xolani, the caregiver, for the healing of his circumcision, but Kwanda is "city smart" and in many ways looks down on the other young men as "villagers". Through all of this complication, they develop a kind-of relationship, and begin to see each other. However, after Kwanda catches Xolani and Vija postcoital and in each other's arms, he acts unkindly and threatens to expose the relationship between Xolani and Kwanda. Vija chases Kwanda and he runs and disappears. Xolani goes looking for Kwanda and finds him, and it's just the two of them walking and talking. In their conversation, out of the "mountain attire" and dressed in civilian clothes, Kwanda partly "teaches" Xolani about gay African history invoking the famed same-sex escapades of Shaka Zulu and his warriors, but also puts pressure on Xolani by taunting him to "come out" and live openly. Xolani responds to Kwanda's taunts by pushing him off a cliff and Kwanda presumably dies. The death of Kwanda can be read in many different ways. I see the murder of Kwanda as an expression of Xolani's internalised homophobia, evident throughout the film. It is a demonstration of Xolani wanting to kill the queer inside himself.

\section{Inxeba and the Possibilities for Xhosa Culture}

The film Inxeba provokes a conversation about Xhosa culture and the creation of men within Xhosa cultural practices. The film asks us, as Xhosa people, to question our ideas about Xhosa manhood, how that manhood is made, and what Xhosa culture's responsibility is towards queer Xhosa men. My contention is that the film challenges Xhosa culture and warrants us to imagine different possibilities of engaging queerness in Xhosa culture. The strong reactions against the film were typically interpreted as a reaction towards the exposure of Xhosa culture to the world, and the exposure was constructed as damaging to Xhosa culture (Siswana and Kiguwa 2018). The question of "exposure" is complicated. Not only is it a limited way of reading the film, it positions the film in a vacuum. Firstly, what is "exposed" by the film has already been exposed in academic research papers and in memoirs. Examples include Mandela's (1994) biography, Long Walk To Freedom, and fictional works like A Man Who is Not A Man by Mgqolozana (2009) and Touré's (2015) Piggy Boy's Blues.

None of these works received the hate and the militant efforts to shut them down that the film did. Secondly, the "exposure" of initiation practices really became part of public discourse because of the high death rates of boys on the mountain, to a point where public health initiatives had to be instituted. Equally important, the reporting on the deaths of initiates takes place in a democratic South Africa where there is much more 
focus on African lives than there was under apartheid because black people are now part of a larger South Africa. Thirdly, the discussion of African cultural practices is difficult in South Africa because there is a history of the misrepresentation of African cultures understood through Eurocentrism. This is a valid concern. However, it is highly problematic to regulate Xhosa culture while being preoccupied with the response from "outsiders" and/or white people. What kind of ethics are being practised when Xhosa queer boys are saying this is my experience, and the concern is do not "expose" culture? This position gives whiteness power, even in absentia, to regulate how Xhosa people express and respond to issues within Xhosa culture. Fourthly, I have written elsewhere about the contradictions of postcolonial existence, and the need for a nuanced understanding of Xhosa cultural practices (Scott 2020). I wrote about the dangers of understanding Xhosa culture as static by demonstrating the many changes in Xhosa cultural practices over years, changes fuelled in part by colonialism, urbanisation, Xhosa people's desires, and now in post-apartheid South Africa, changes are influenced by democracy and digitisation. Considering Gqola and Goniwe's (2005) assertion about protectionism of culture, I restate that these "exposure" reactions make sense, but there is more at stake here because the Xhosa rites of passage for boys were already well documented without fanfare. This leads to the conclusion that the reason for the hostile reactions towards the film is rather related to the subject matter, namely the queerness of the film. The film pushes the boundary of what can be included in stories about Xhosa culture and Xhosa masculinity. It is wise for us to remember that men live with "the fear of being perceived homosexual" (Ratele 2014, 116) and it is through the demonstration of contempt for the queer that non-homosexual manhood is displayed. This is what the film is against as it boldly asserts queerness at the heart of Xhosa culture and demands that Xhosa culture take queerness seriously.

Just as Kwanda and his father are characterised as polluted Xhosa people in the film, in the aftermath of Inxeba, many have characterised the film as polluting Xhosa culture, of making the culture impure, and of distorting the culture. Both instances rely on the idea that Xhosa culture is pure, that it is as it has always been, and that it is fixed and stable. I am arguing that the contrary is true, and that this is partly the force behind Inxeba because it makes obvious the deviations from the dominant norm, and shows the instability that is inherent in masculinities and in Xhosa culture. Thus through the multiple ways in which we interpret Inxeba we cannot ignore the historically complex ways that have come to shape Xhosa culture and people. The film Inxeba enables us to see the operations of the stratification of South Africa, particularly as black South Africans wrestle with the difficult history of colonialism and apartheid. The film is a crossroads of blackness, same-sex desire, masculinities and Xhosa culture. It is also a political project in that it is dealing with the subject matter of same-sex desire in Xhosa cultural and traditional spaces that are at best ambivalent about same-sex desire, even though this exists in those spaces. The film is a congregation of all these different elements, within the narrative of the film, as well as in the reactions towards the film in the public sphere. Consequently, in responding to Inxeba it is of utmost importance that we consider these complicated journeys that Xhosaness has made if we are to gain a better grasp of what Inxeba is and what it means for black, specifically Xhosa, masculinities and for queer politics in post-apartheid South Africa. 


\section{Conclusion}

Inxeba is a film that challenges dominant ideas about masculinity through the intersection of Xhosa culture and queerness. This article has focused on the film's provocation for conversation about difference and how difference manifests itself in Xhosa culture. The film is a critical intervention that opens up a space for imagining alternative configurations for queer Xhosa boys and men within Xhosa culture, by demonstrating the damaging hostility within the Xhosa culture that stifles alternative sexualities. The characters in Inxeba portray the convoluted and difficult position in which queer Xhosa boys and men find themselves, of wanting to be part of their culture but being asked to be part of the culture through a denial of who they are. Of course, this is the African queer conundrum articulated succinctly by Ratele as "being part of a culture yet partially apart from it, a sense of being torn and having multiple belongings, [which] is of course central in thinking of not only homosexual Africans but of oppressed sexual identities generally" $(2013,149)$.

The hostility towards the film Inxeba was ultimately grounded in homophobia disguised as the preservation of culture. The rejection of the film by mostly cisgender men demonstrates the desire to hold on to power through cultural institutions and practices in spaces where dominant forms of heteropatriarchy cannot be questioned. The hostility towards Inxeba was exactly motivated by the film's challenges to traditional heteropatriarchal homophobic power and its insistence on queer narratives within black cultural spaces. The film asserts that queer Xhosa boys and men matter and that the complex terrain in which their intimacies operate and find voice needs to be engaged fully. Inxeba summons a different future for queer Xhosa boys and men and in turn for all black boys and men in South Africa. It provides an articulation of black queer bodies and their interaction with black cultural traditions that challenges normative assumptions about black boys and men and their culture, and we are all better for it.

\section{Note}

1. The word "boy" is used here specifically to make clear the difference between "boys" and "men" in Xhosa culture in that "boys" have not gone through the initiation process, whereas "men" have.

\section{Acknowledgement}

The author acknowledges the Centre for Humanities Research of the University of the Western Cape for the fellowship award that facilitated the writing of this paper.

\section{Disclosure statement}

No potential conflict of interest was reported by the author(s).

\section{References}

Ally, Shireen. 2009. From Servants to Workers: South African Domestic Workers and the Democratic State. Ithaca, NY: ILR Press.

Amadiume, Ifi. 1987. Male Daughters, Female Husbands: Gender and Sex in an African Society. London: Zed Books. 
Collison, Carl. 2018. "Inxeba Wounds Our Cultural Practice". Mail \& Guardian. https://mg.co.za/article/ 2018-02-02-00-inxeba-wounds-our-cultural-practice.

Delius, Peter. 2017. "The History of Migrant Labor in South Africa (1800-2014)". Oxford Research Encyclopedia of African History.

De Vos, Pierre. 2001. "The Constitution Made Us Queer: The Sexual Orientation Clause in the South African Constitution and the Emergence of Gay and Lesbian Identity." In Law and Sexuality in the Global Arena, edited by Carl Stychin and Didi Herman, 194-207. Minneapolis, MN: University of Minneapolis Press.

Dunbar Moodie, T. 1988. "Migrancy and Male Sexuality on the South African Gold Mines." Journal of Southern African Studies 14 (2): 228-256.

Epprecht, Mark. 2004. Hungochani: The History of a Dissident Sexuality in Southern Africa. Montreal: McGill-Queen's University Press.

Gqola, Pumla Dineo, and Thembinkosi Goniwe. 2005. "A Neglected Heritage: The Aesthetics of Complex Black Masculinities." Agenda (63): 80-94.

Gqola, Pumla Dineo. 2007. "'A Woman Cannot Marry a Boy': Rescue, Spectacle and Transitional Xhosa Masculinities." In From Boys to Men: Social Constructions of Masculinity in Contemporary Society, edited by Tamara Shefer, Kopano Ratele, Anna Strebel, Nokuthula Shabalala, and Rosemarie Buikema, 145-160. Cape Town: UCT Press.

Heasley, Robert. 2005. "Queer Masculinities of Straight Men." Men and Masculinities 7 (3): 310-320.

Jansen, Ena. 2019. Like Family: Domestic Workers in South African History and Literature. Johannesburg: Wits University Press.

Judge, Melanie, Anthony Manion, and Shaun de Waal. 2008. To Have and To Hold: The Making of Same-Sex Marriage in South Africa. Cape Town: Jacana Media.

Judge, Melanie. 2018. Blackwashing Homophobia: Violence and the Politics of Sexuality, Gender and Race. London: Routledge.

Kendall. 2001. "When a Woman Loves a Woman' in Lesotho: Love, Sex, and the (Western) Construction of Homophobia." In Boy-Wives and Female-Husbands: Studies in African Homosexualities, edited by Stephen Murray and Will Roscoe, 223-242. New York, NY: Palgrave Macmillan.

Khoza, Amanda. 2018. "Inxeba (The Wound): Court Rules That Film Is Not Hardcore Porn." News24. https://www.news24.com/SouthAfrica/News/inxeba-the-wound-court-rules-that-film-is-nothardcore-porn-20180628.

Mandela, Nelson. 1994. Long Walk to Freedom. Johannesburg: Macdonald Purnell.

Masuabi, Queenin. 2018. "Traditional Leaders on 'Inxeba' 'We Are Not Homophobic, But...'". Huffington Post. https://www.huffingtonpost.co.uk/2018/02/14/contralesa-we-are-not-homopho bic-but_a_23361605/?guccounter=1\&guce_referrer=aHROcHM6Ly93d3cuZ29vZ2xILmNvbS8\& guce_referrer_sig=AQAAAGcSQoKOdOecBCO6-4Stsy61XiC6ck_KRmiTBQQt0Uvg-afle6_IXk38569 DJ7DjlcINb-PdjjypdwOSyi_BwN-odTUOC9fBJnHKLQD5as2h7r9V_Sg92qfPzAK0QSTekxhAFAonxv LceOTa_D9CWvGq1NDb_7AaGDsneu_2QYcY.

Mbembe, Achille Joseph. 2001. On the Postcolony. Berkeley, CA: University of California Press.

Mfecane, Sakhumzi. 2018. "Towards African-Centred Theories of Masculinity." Social Dynamics 44 (2): 291-305.

Mgqolozana, Thando. 2009. A Man Who Is Not a Man. Scottsville: University of KwaZulu-Natal Press. Mkhize, Nonhlanhla, Jane Bennett, Vasu Reddy, and Relobohile Moletsane. 2010. The Country We Want to Live In: Hate Crimes and Homophobia in the Lives of Black Lesbian South Africans. Cape Town: HSRC Press.

Morgan, Ruth, and Saskia Wieringa. 2005. Tommy Boys, Lesbian Men, and Ancestral Wives: Female Same-Sex Practices in Africa. Johannesburg: Jacana Media.

Morrell, Robert., ed. 2001. Changing Men in Southern Africa. Pietermartizberg: University of Natal Press.

Murray, Stephen, and Roscoe, Will. 1998. Boy-Wives and Female Husbands: Studies of African Homosexualities. New York, NY: Palgrave Macmillan. 
O'Reilly, Anthena, and Julia Madibogo. 2018. "Inxeba Cast Members Moved to Safe House Amidst Security Threats." Sowetan Sunday World. https://www.sowetanlive.co.za/sundayworld/news/ 2018-02-08-inxeba-cast-members-moved-to-safe-house-amidst-security-threats/.

Ouzgane, Lahoucine, and Robert Morrell, eds. 2005. African Masculinities: Men in Africa From the Late Nineteenth Century to the Present. New York, Basingstoke and Pietermaritzberg: Palgrave MacMillan and University of KwaZulu-Natal Press.

Oyěwùmí, Oyèrónkẹ. 1997. The Invention of Women: Making an African Sense of Western Gender Discourses. Minneapolis, MN: University of Minnesota Press.

Pigou, Piers. 2001. "The Apartheid State and Violence: What Has the Truth and Reconciliation Commission Found?" Politikon 28 (2): 207-233.

Ratele, Kopano. 2008. "Studying Men in Africa Critically." In Masculinities in Contemporary Africa, edited by Egodi Uchendu, 18-33. Dakar: CODESRIA.

Ratele, Kopano. 2013. "Masculinities Without Tradition." Politikon 40 (1): 133-156.

Ratele, Kopano. 2014. “Hegemonic African Masculinities and Men's Heterosexual Lives: Some Uses for Homophobia." African Studies Review 57 (2): 115-130.

Ratele, Kopano. 2017. "African (Situated) Psychologies of Boys, Men and Masculinities." Psychology in Society 54: 10-28.

Sachs, Albie. 1970. South Africa: The Violence of Apartheid. London: Christian Action.

Scott, Lwando. 2019. "Harnessing the Power of Queerness." In They Called Me Queer, edited by Kim Windvogel and Kelly-Eve Koopman, 22-39. Cape Town: Kwela Books.

Scott, Lwando. 2020. "Queering the Postcolony: Same-Sex Desire and Xhosa Culture in Postcolonial South Africa." In The SAGE Book of Global Sexualities, edited by Zowie Davy, Ana Cristina Santos, Chiara Bertone, Ryan Thoreson, and Saskia E. Wieringa, 422-441. London: Sage.

Siswana, Anele, and Peace Kiguwa. 2018. "Social Media Representations of Masculinity and Culture in Inxeba (The Wound)." Agenda 32 (3): 53-61.

Touré, Nakhane. 2015. Piggy Boy's Blues. Johannesburg: Jacana Media.

Trengove, John. 2017. Inxeba (The Wound). DVD. Johannesburg: Urucu Media.

Uchendu, Egodi. 2008a. Masculinities in Contemporary Africa. Dakar: CODESRIA.

Uchendu, Egodi. 2008b. "Introduction: Are African Males Men? Sketching African Masculinities." In Masculinities in Contemporary Africa, edited by Egodi Uchendu, 1-17. Dakar: CODESRIA.

Zeeman, Kyle. 2018. "Eastern Cape Cinemas Cancel Screenings of Inxeba (The Wound) Amid Threats". Times Live. https://www.timeslive.co.za/tshisa-live/tshisa-live/2018-02-02-movie-houses-cancelscreening-of-the-wound-inxeba-amid-threats/. 